\title{
ANTIBACTERIAL ACTIVITIES OF BELIMBING WULUH (AVERRHOA BILIMBI L.) ETHYL ACETATE EXTRACT ON GEL FORMULATED AGAINST PROPIONIBACTERIUM ACNES AND STAPHYLOCOCCUS AUREUS
}

\section{DEWI PERTIWI ${ }^{*}$, IHSANUL HAFIZ ${ }^{2}$, WARDATUL JANNAH ${ }^{2}$, HANAFIS SASTRA WINATA ${ }^{2}$, MELIA SARI ${ }^{2}$, RAZIA BEGUM SUROYO ${ }^{3}$}

1Department of Pharmaceutical Biology, Faculty of Pharmacy, Universitas Sumatera Utara, Medan 20155, Indonesia, ${ }^{2}$ Faculty of Pharmacy and Health, Institut Kesehatan Helvetia, Medan 20124, Indonesia, ${ }^{3}$ Faculty of Public Health, Institut Kesehatan Helvetia, Medan 20124, Indonesia

Email: dewipertiwi@usu.ac.id

Received: 15 Aug 2020, Revised and Accepted: 16 Sep 2020

\section{ABSTRACT}

Objective: Averrhoa bilimbi is a plant that is used as a food spice and traditional medicine in Indonesia. The purpose of this study was to obtain a gel formula and measure its activity in inhibiting the growth of skin bacteria, namely Propionibacterium acnes and Staphylococcus aureus.

Methods: The gel formulation was tested organoleptically, homogeneity, $\mathrm{pH}$, dispersibility test, and skin irritation test. Antibacterial activity test using agar diffusion method, inhibition of bacterial growth was compared with clindamycin as a positive control.

Results: All gel formulations showed good homogeneity, $\mathrm{pH}$ of the preparations ranged from 4.5 to 6.1 , the dispersion test was 5.5-6.5 cm, and none of them caused irritation to the skin. The results of the inhibitory activity against the growth of Propionibacterium acnes bacteria on concentrations 10,15 , and $20 \%$ were $16.67+0.40,22.70+0.32$ and $28.10+0.36$ and Staphylococcus aureus bacteria were $18.53+0.22,24.16+0.29$ and $30.40+$ 0.4 . The inhibitory activity of clindamycin against Propionibacterium acnes and Staphylococcus aureus bacteria were $35.33+0.29$ and $36.30+0.37$.

Conclusion: Ethyl acetate extract gel Averrhoa bilimbi had good activity in inhibiting the growth of Propionibacterium acnes and Staphylococcus aureus bacteria and has the potential to be used as an herbal anti-acne drug.

Keywords: Antibacterial activities, Averrhoa bilimbi, Gel formulation, Propionibacterium acnes, Staphylococcus aureus

(c) 2020 The Authors. Published by Innovare Academic Sciences Pvt Ltd. This is an open access article under the CC BY license (http://creativecommons.org/licenses/by/4.0/) DOI: http://dx.doi.org/10.22159/ijap.2020v12i6.39406. Journal homepage: https://innovareacademics.in/journals/index.php/ijap

\section{INTRODUCTION}

Averrhoa bilimbi is known in Indonesia as Belimbing Wuluh or Asam Sunti, a plant that is often used for cooking spices and traditional medicine [1]. Averrhoa bilimbi is an important medicinal tree in the tropical and subtropical regions, especially in Asia and has been used to treat different medical conditions. Traditionally, Averrhoa bilimbi is used to treat fever, inflammation, diabetes, hypertension, rheumatism, flu, stiff, poisonous animal bites, itching and skin disorders [2-4].

Averrhoa bilimbi contains flavonoids luteolin and apigenin which are useful as antibacterial agents and can be used as acne medicine [5]. It is known that the total flavonoid content in Averrhoa bilimbi is $1.67+0.87 \mathrm{mg} / \mathrm{g}$ QE and total phenolic $38.78+0.94 \mathrm{mg} / \mathrm{g}$ GAE and its ability in scavenging DPPH free radicals is $635.06+8.41 \mathrm{ug} / \mathrm{ml}(6)$. It is known that the ethyl acetate extract of Averrhoa bilimbi actives inhibits the growth of Escherichia coli and Staphyococcus aureus bacteria [7]. Other research conducted by Ikhsanudin (2017) proved the gel preparation from the ethanol extract of Averrhoa bilimbi fruit could inhibit the growth of Propionibacterium acnes bacteria [8].

Besides actively inhibiting bacteria, Averrhoa bilimbi has been shown to have analgesic and anti-inflammatory activity. The methanol extract of leaves provide an analgesic effect on mice and anti-inflammatory against rats at a dose of $400 \mathrm{mg} / \mathrm{kg}$. In another method, the ethanol extract leaves was tested on cow blood to see the red blood cell hemolysis barrier to illustrate the stabilization of the red blood cell membrane so as to prevent the inflammation process in the tissue. In this method the extract is able to inhibit active hemolysis at concentrations of 200-600 ug/ml [4, 9].

Based on the activity of Averrhoa bilimbi which is good in suppressing inflammation and growth of Staphylococcus aureus and Propionibacterium acnes bacteria, which are the factors causing acne, this plant has the potential to be used as an anti-acne drug made from active extracts. This research carried out the development by converting the ethyl acetate extract from Averrhoa bilimbi fruit into a gel, which was then tested on the growth of Staphylococcus aureus and Propionibacterium acnes bacteria.

\section{MATERIALS AND METHODS}

Methods

\section{Chemicals and instruments}

The chemicals used are ethyl acetate, carbomer 934, methylparaben, glycerin, triethanolamine, distilled water, nutrient agar, $\mathrm{NaCl} 0.9 \%$ $\mathrm{H} 2 \mathrm{SO} 4$ 1\%, BaCl2 1.175\%, Mediklin ${ }^{\circledR}$ Gel. The bacteria used were Staphylococcus aureus ATCC ${ }^{\circledR} 25923^{\mathrm{m}}$ and Propionibacterium acnes ATCC ${ }^{\circledR} 6919^{m}$. The instruments used were analytical scales, glassware, blender, $\mathrm{pH}$ meter, micropipette, digital term, oven, autoclave, and incubator.

\section{Plant material collection and extraction}

Averrhoa bilimbi fruit was obtained from the garden of residents in Dusun Tiga, Sunggal District, Medan, Indonesia. Plant determination was carried out by Herbarium Medanense (MEDA), Universitas Sumatera Utara with document number 4544/MEDA/2019 with the result of the plant species being Averrhoa bilimbi L.

Averrhoa bilimbi fruit was washed and chopped then dried in a drying cabinet for $3 \mathrm{~d}$ at a temperature of $40-50{ }^{\circ} \mathrm{C}$. The dry simplicia was then crushed in a blender machine. The powder was extracted using ethyl acetate by the maceration method. On the third day, the maceration results were separated from the dregs. The results of maceration were concentrated using a rotary evaporator to obtain a thick extract. The thick extract obtained is used as the active ingredient of the gel.

\section{Gel formulation}

The gel is made in 4 variations of the concentration of the active substance, namely $0,10,15$ and $20 \%$. The gel formula can be seen in table 1. 
Table 1: Formula of Averrhoa bilimbi gel (10)

\begin{tabular}{lllll}
\hline No & Materials & \multicolumn{2}{l}{ Concentration (gram) } \\
\cline { 3 - 5 } & & F0 & F1 (10\%) & F2 (15\%) \\
\hline 1 & Averrhoa bilimbi Extract & - & 2.5 & 3.7 \\
2 & Carbomer 934 & 0.25 & 0.25 & 0.25 \\
3 & Methyl Paraben & 0.05 & 0.05 & 0.05 \\
4 & Glycerin & 1.25 & 1.25 & 0.25 \\
5 & Triethanolamine & 0.25 & 0.25 & 0.25 \\
6 & Distilled water up to & 25 & 25 & 0.25 \\
\hline
\end{tabular}

The chemicals needed are weighed according to the formula, put the carbomer 934 into a clean and dry mortar then dissolve it with some hot water and crush it to form a gel base, add methylparaben and glycerin and crush until homogeneous, then add extract and triethanolamine into base until homogeneous. Next, add distilled water, homogenize it to form a gel, then the gel preparations that were ready to be made are put into the container $[10,11]$.

\section{Gel formula evaluations}

The evaluation of the formula included organoleptic test, homogeneity, $\mathrm{pH}$ value; surface disperse ability, and skin irritation test. Organoleptic test was carried out by direct observation to the shape, color, and smell of the gel made. The characterization of the gel formula was studied in more depth after refining the formula in further research. The gel is usually clear with a semi-solid consistency. The homogeneity test is carried out by applying the gel sample to a piece of glass or other suitable transparent material, the preparation must show a homogeneous structure and no coarse grains are visible $[12,13]$.

The $\mathrm{pH}$ meter was first calibrated using a standard neutral buffer solution ( $\mathrm{pH} 7.01)$ and an acid buffer solution (pH 4.01) until the tool shows the $\mathrm{pH}$ value. Then the electrode is washed with distilled water, then dried with a tissue. 1 gram of gel to be examined was diluted with $100 \mathrm{ml}$ of distilled water. The electrodes are immersed in the solution being examined, the tool is allowed to show the $\mathrm{pH}$ value until it is constant. The number shown by the $\mathrm{pH}$ meter is the $\mathrm{pH}$ of the preparation. The $\mathrm{pH}$ of gel must be in accordance with the skin $\mathrm{pH}$, specifically $4.5-6.5[12,13]$.

0.5 grams of gel is weighed and placed in the middle of a round glass. The round glass cover is weighed first, then placed over the gel mass and left for 1 minute. The length of the diffused gel diameter was measured, then 150 grams of additional weight was added, left for 1 minute and the diameter of the gel spread was recorded. The addition of the load is continued until a constant diameter is obtained. The spreadability of 5-7 cm indicates a semisolid consistency, which is very comfortable in use $[12,13]$.

The irritation test was carried out on 10 volunteers who each affixed the test material, namely F0 (without extract), F1 (10\% extract), F2 (15\% extract), F3 (20\% extract), the gel was applied to the back of the volunteer's hands 3 times a day in an interval of $8 \mathrm{~h}$ for three consecutive days. Look for changes that occur, in the form of irritation with characteristics the skin becomes rough, itchy, and reddish $[12,13]$. This irritation test has been approved by Health Research Ethical Committee of North Sumatera/RSUP H Adam Malik c/o Medical School, Universitas Sumatera Utara No 105/Komet/FK USU/2019.

\section{Antibacterial activity test}

All tools used for the antibacterial test were washed with clean water, then wrapped in paper. Tools made of glass (heat resistant) are sterilized in the oven at a temperature of $160-170{ }^{\circ} \mathrm{C}$ for $1-2 \mathrm{~h}$, the bacterial growth media are sterilized in autoclave at $121^{\circ} \mathrm{C}$ for $15 \mathrm{~min}$, and round loop or loop needles are sterilized on flame fire $[13,14]$.

The nutrient agar (NA) is dissolved with distilled water $(23 \mathrm{~g} / 1000$ $\mathrm{ml}$ ) in an erlenmeyer then cover the erlenmeyer tightly using a cotton pad covered with paper and tie it with a rope. Then homogenize it on a water bath until it boils. Then sterilize it in an autoclave for $15 \mathrm{~min}$ at $121^{\circ} \mathrm{C}$ [15].

Each bacterial culture was taken from the media to slant using a round loop then put into a test tube containing $10 \mathrm{ml}$ of $0.9 \% \mathrm{NaCl}$, stirring until homogeneous. The level of the suspension solution was adjusted to the turbidity of the Mc Farland solution $[16,17]$.

Prepare a sterilized petri dish. Put $0.1 \mathrm{ml}$ of the bacterial suspension into a petri dish. Then $20 \mathrm{ml}$ of NA media were added, stirring until homogeneous and allowed to solidify. Furthermore, a pit is made using a metal holder. Then the well that has been made is inserted with a gel preparation as much as $0.05 \mathrm{~g}$. Then it is incubated in an incubator for $24 \mathrm{~h}$ at a temperature of $35-37^{\circ} \mathrm{C}$ and measured the diameter of the resistance zone (clear zone) that is formed [13].

\section{Data analysis}

The data obtained is presented in tabular form, then the data obtained from the research results are processed by statistical analysis of variance (ANOVA) tests.

\section{RESULTS AND DISCUSSION}

\section{Gel Formula evaluations}

Organoleptic test results of Averrhoa bilimbi L. fruit ethyl acetate extract gel are: the resulting gel had a semi-solid form, brown to blackish-brown in color and the resulting odor was the distinctive aroma of the extract from each preparation. All formulas show good homogeneity, and the $\mathrm{pH}$ of each formula is in the range 4.5-6.1. The diameter of the surface dissipation power is $5.5-6.5 \mathrm{~cm}$. Neither formula caused skin irritation in the study process. The results of the organoleptic test can be seen in table 2. The results of the homogeneity, $\mathrm{pH}$, and dispersion can be seen in table 3 , and the results of the skin irritation test in table 4 .

Table 2: Organoleptic test results

\begin{tabular}{llll}
\hline Formulas & Consistence & Color & Odor \\
\hline F0 & Semisolid & Transparent & Odorless \\
F1 & Semisolid & Brown transparent & the distinctive smell of the extract \\
F2 & Semisolid & Blackish brown transparent & \\
F3 & Semisolid & Blackish brown transparent & \\
\hline
\end{tabular}

Table 3: The result of homogeneity, $\mathrm{pH}$, and disperse of gel

\begin{tabular}{llll}
\hline Formula & Homogeneity & pH Value & Disperse Value \\
\hline F0 & Homogeneous & $6.06 \pm 0.03$ & $6.53 \pm 0.03$ \\
F1 & Homogeneous & $4.86 \pm 0.03$ & $6.06 \pm 0.03$ \\
F2 & Homogeneous & $4.70 \pm 0.00$ & $5.76 \pm 0.03$ \\
F3 & Homogeneous & $4.53 \pm 0.03$ & $5.46 \pm 0.03$ \\
\hline
\end{tabular}

The data of $\mathrm{pH}$ and disperse value presented were the average $\mathrm{pH}$ value \pm SEM where each group was repeated three times 
There was no significant difference between the test groups in physical appearance and the value of $\mathrm{pH}$ and disperse measurements ( $p>0.05)$. indicates that each formula has the same characteristics. The physical test results prove that the gel preparation meets the gel quality test parameters, namely the organoleptic test, the form is semisolid, the color and smell are in accordance with the concentration of the extract it contains. Based on these results, it was concluded that the more extracts that were added to each formula, the color would be darker. The results of homogeneity examinations of each concentration of gel formulations F0, F1, and F2 and F3 showed homogeneous results and did not show any coarse grains when the preparation was applied to the glass object. This indicated that the preparations made had a homogeneous structure $[18,19]$.

The $\mathrm{pH}$ value shows that the higher the extract concentration contained in the gel, the lower the $\mathrm{pH}$ value. The change in $\mathrm{pH}$ value is not significantly different $(\mathrm{p}>0.05)$. The $\mathrm{pH}$ value of a topical pharmaceutical product should correspond to a skin $\mathrm{pH}$ of 4.5-6.5. Based on table 4.3, the $\mathrm{pH}$ measurement results of each formula show the $\mathrm{pH}$ value of each gel formula according to the skin's $\mathrm{pH}$ range so it is safe to use [20-22].

The dispersion test also did not show any significant difference for each formula ( $p>0.05)$; however, based on the smaller the dispersion value as the extract concentration increased, it showed that there was a slight change inconsistency when the dispersion was carried out. The gel formula that was formed met the dispersion test parameters $(5-7 \mathrm{~cm})$. The test was carried out on all the gel formulas. The additional load on the extract will also increase the spread area of the gel. Increasing the load illustrates a dispersive characteristic of semisolid preparations. The more the gel spreads due to the additional load, the conclusion is that its ability to distribute the drug is more evenly distributed. The test is carried out to see the consistency of the preparation, as well as to observe the dispersion of the preparation when applied to the skin so that it is hoped that the area on the skin will get the active substance with the same dose evenly. The test results show that the gel has consistency and results in good surface dispersion [23-25].

Table 4: The result of skin irritation test

\begin{tabular}{|c|c|c|c|c|c|c|c|c|c|c|c|}
\hline \multirow[t]{2}{*}{ Observations } & \multirow[t]{2}{*}{ Formulas } & \multicolumn{10}{|c|}{ Volunteer } \\
\hline & & 1 & 2 & 3 & 4 & 5 & 6 & 7 & 8 & 9 & 10 \\
\hline \multirow[t]{4}{*}{ Reddish Skin } & F0 & - & - & - & - & - & - & - & - & - & - \\
\hline & $\mathrm{F} 1$ & - & - & - & - & - & - & - & - & - & - \\
\hline & $\mathrm{F} 2$ & - & - & - & - & - & - & - & - & - & - \\
\hline & F3 & - & - & - & - & - & - & - & - & - & - \\
\hline \multirow[t]{4}{*}{ Rough Skin } & F0 & - & - & - & - & - & - & - & - & - & - \\
\hline & $\mathrm{F} 1$ & - & - & - & - & - & - & - & - & - & - \\
\hline & $\mathrm{F} 2$ & - & - & - & - & - & - & - & - & - & - \\
\hline & F3 & - & - & - & - & - & - & - & - & - & - \\
\hline \multirow[t]{4}{*}{ Itchy Skin } & F0 & - & - & - & - & - & - & - & - & - & - \\
\hline & $\mathrm{F} 1$ & - & - & - & - & - & - & - & - & - & - \\
\hline & $\mathrm{F} 2$ & - & - & - & - & - & - & - & - & - & - \\
\hline & F3 & - & - & - & - & - & - & - & - & - & - \\
\hline
\end{tabular}

Explanation+: Irritation Symptoms occur (reddish, rough, and itchy),-: There are no symptoms or irritation

Table 5: Antibacterial activity of $A$. bilimbi gel

\begin{tabular}{lll}
\hline Formulas & Inhibition diameters (mm) & \\
\cline { 2 - 3 } & Propionibacterium acnes+SEM & Staphylococcus aureus+SEM \\
\hline Positive Control & $35.3333 \pm 0,29059^{*}$ & $36.3000 \pm 0,37859^{*}$ \\
F0 (Negative Control) & $0000 \pm 00000$ & $0000 \pm 00000$ \\
F1 (10\%) & $16.6667 \pm 0,42557^{*}$ & $18.5333 \pm 0,21858^{*}$ \\
F2 (15\%) & $22.7000 \pm 0,32146^{*}$ & $24.1667 \pm 0,29059^{*}$ \\
F3 (20\%) & $28.1000 \pm 0,36056^{*}$ & $30.4000 \pm 0,40415^{*}$ \\
\hline
\end{tabular}

The data presented is the value of inhibition diameter $(\mathrm{mm})+$ SEM. ${ }^{*}$ significantly different to negative control $(\mathrm{p}<0.05)$

The skin irritation test was carried out by applying a gel preparation on the backs of the volunteers' hands for three consecutive days, the results showed that all volunteers had a negative effect on the parameters of the irritation reaction. From the results of the irritation test, it can be concluded that the gel preparation is safe for topical use [26-28].

\section{The results of antibacterial activity}

The results of the antibacterial activity test of Averrhoa bilimbi ethylacetate extract gel against Propionibacterium acnes and Staphylococcus aureus can be seen in table 5. MIC values were not calculated from this study. This study was limited to the ratio of the inhibition zone diameter of the gel to the growth of bacteria in nutrient agar media.

The positive control used was a gel containing clindamycin (Mediklin $囚$ ) and the negative control used was a gel base without any active substances. Inhibition value resulted from the test showed that positive control had a very strong ability compared to other groups, and negative control did not have inhibitory power against bacterial growth. The formula containing the test sample showed significant inhibition $(\mathrm{p}<0.05)$ compared to the negative control. Based on the results data, it can be concluded that the higher the extract concentration in a given preparation, the greater the antibacterial activity of the gel. This is in accordance with the theory put forward by Pelczar and Chan that the greater the concentration of antimicrobial compounds being tested, the greater the antimicrobial activity of these compounds $[29,30]$.

The clear zone around the well is caused by the active substance content of Averrhoa bilimbi fruit ethyl acetate extract gel, which contains flavonoids, alkaloids, saponins, terpenoids and tannins which can function as antibacterial $[3,31]$. Flavonoid compounds have the ability to form complexes with bacterial cell proteins through hydrogen bonds. The structure of the cell wall and bacterial cytoplasmic membrane, which contains protein, becomes unstable because the protein structure of bacterial cells is damaged due to hydrogen bonds with flavonoids, so that the bacterial cell protein loses its biological activity, as a result, the function of bacterial cell permeability is disrupted and results in bacterial cell death [32-34]. Alkaloids have antibacterial abilities and inhibitory mechanisms by interfering with the components of the peptidoglycan composition 
in bacterial cells so that the wall layer is not formed completely and causes bacterial death [35-37].

\section{CONCLUSION}

Gel with active ethyl acetate extract of Averrhoa bilimbi has good formula characteristics and fulfills the requirements in all formula evaluations. The gel shows no symptoms of skin irritation and meets simple basic requirements (organoleptic, homogeneity and $\mathrm{pH}$ ). This gel also has good antibacterial activity so that it can inhibit the growth of the Propionibacterium acnes and Staphylococcus aureus bacteria which are generally a problem on the skin such as wounds and acne. Based on the research results, it can be considered as the cause of herbal remedies to treat wounds and acne, but it is necessary to develop a more in-depth formula and test.

\section{FUNDING}

Nil

\section{AUTHORS CONTRIBUTIONS}

All the authors have contributed equally.

\section{CONFLICT OF INTERESTS}

All author had no to declare

\section{REFERENCES}

1. Xu E, Wijaya $\mathrm{CH}$, Faridah DN. Characterization of aroma compounds in traditional Indonesian seasoning (asam sunti) made from Averrhoa bilimbi L. Emirates J Food Agric 2017;29:378-86.

2. Samuel AJSJ, Kalusalingam A, Chellapan DK, Gopinath R, Radhamani S, Husain A, et al. Ethnomedical survey of plants used by the orang asli in kampung bawong, perak, West Malaysia. J Ethnoniol Ethnomed 2010;6:1-6.

3. Alhassan MA, Ahmed QU. Averrhoa bilimbi linn.: a review of its ethnomedicinal uses, phytochemistry, and pharmacology. J Pharm Bioallied Sci 2016;8:265-71.

4. Miraj AJ, Kabir A, Mamun Y, Akhter S, Ahammed MS, Sultana S, et al. Evaluation of the analgesic and anti-inflammatory activities of methanolic extracts of the leaves of averrhoa bilimbi leaves. Discovery Phytomed 2019;6:12-5.

5. Yulianingtyas A, Kusmartono B. Optimization of solvent volume and maceration time on extraction of flavonoids from averrhoa bilimbi leaves. J Tek Kim 2016;10:58-64.

6. Rahman M, Habib R, Hasan A, Al Amin M, Saha A, Mannan A. Comparative assessment on in vitro antioxidant activities of ethanol extracts of averrhoa bilimbi, gymnema sylvestre and capsicum frutencens. Pharmacognosy Res 2014;6:36-41.

7. Seebaluck Sandoram R, Lall N, Fibrich B, van Staden AB, Saleem H, Mahomoodally MF. Antimicrobial, antioxidant and cytotoxic evaluation of two underutilised food plants: averrhoa bilimbi l. (Oxalidaceae) and phyllanthus acidus L. skeels (Phyllanthaceae). Biocatal Agric Biotechnol 2019;18:100998.

8. Ikhsanudin A, Mardhiyah S. Formulasi dan uji antijerawat gel ekstrak etanol 70\% buah belimbing wuluh (Averrhoa Bilimbi Linn.) terhadap bakteri propionibacterium acnes. Medula 2017;5:416-26

9. Hasim, Rifin YY, Andrianto D, Faridah DN. Ethanol extracts of averrhoa bilimbi leaf demonstrated antioxidative and antiinflammatory activity. J Appl Teknol Pangan 2019;8:86-93.

10. Kusuma SAF, Abdassah M, Valas BE. Formulation and evaluation of anti acne gel containing citrus aurntifolia fruit juice using carbopol as gelling agent. Int J Appl Pharm 2018;10:147-52.

11. Jyothi D, Koland M. Formulation and aveluation of an herbal anti-inflammatory gel containing trigonella foenum greacum seed extract. Int J Pharm Pharm Sci 2016;8:41-4.

12. Kaur D, Raina A, Singh N. Formulation and evaluation of carbopol 940 based glibenclamide transdermal gel. Int J Pharm Pharm Sci 2014;6:434-40.

13. Pertiwi D, Hafiz I, Salma R. Antibacterial activity of ethanol extract of papaya leaves (Carica papaya L.) gel against p. acnes. Indones J Pharm Clin Res 2019;2:1-6.
14. Saising J, Hiranrat A, Mahabusarakam W, Ongsakul M, Voravuthikunchai SP. Rhodomyrtone from rhodomyrtus tomentosa (Aiton) hassk. as a natural antibiotic for staphylococcal cutaneous infections. J Heal Sci 2008;54:589-95.

15. Widhianto EK, Elmarda RV, Rakhmawatie MD. Effectivity in vitro of averrhoa bilimbi l ethanolic extract against escherichia coli and staphylococcus aureus growth. Prosiding Seminar Nasional dan Internasional Universitas Muhammadiyah Semarang; 2017. p. 140-8.

16. Mc Farland J. The nephelometer: an instrument for estimating the number of bacteria in suspension used for calculating the opsonic index and for vaccines. JAMA. 1907;XLIX:1176-8.

17. Jaki B, Orjala J, Bürgi HR, Sticher O. Biological screening of cyanobacteria for antimicrobial and molluscicidal activity, brine shrimp lethality, and cytotoxicity. Pharm Biol 1999;37:138-43.

18. Draget KI, Ostgaard K, Smidsrod O. Homogeneous alginate gels: a technical approach. Carbohydratre Polym 1990;14:159-78.

19. Schnepp Z, Zhang Y, Hollamby MJ, Pauw BR, Tanaka M, Matsushita Y, et al. Doped-carbon electrocatalysts with trimodal porosity from a homogeneous polypeptide gel. J Mater Chem A 2013;43:13576-81.

20. Hatanaka T, Morigaki S, Aiba T, Katayama K, Koizumi T. Effect of $\mathrm{pH}$ on the skin permeability of a zwitterionic drug, cephalexin. Int J Pharm 1995;125:195-203.

21. Schmaljohann D. Thermo-and $\mathrm{pH}$-responsive polymers in drug delivery. Adv Drug Delivery Rev 2006;58:1655-70.

22. Martinez Pla JJ, Martin Biosca Y, Sagrado S, Villanueva Camanas RM, Medina Hernandez MJ. Evaluation of the $\mathrm{pH}$ effect of formulations on the skin permeability of drugs by partitioning micellar chromatography. J Chromatogr A 2004;1047:2255-62.

23. Souto EB, Wissing SA, Barbosa CM, Muller RH. Evaluation of the physical stability of SLN and NLC before and after incorporation into hydrogel formulations. Eur J Pharm Biopharm 2004;58:89-90.

24. Edityaningrum CA, Kintoko K, Zulien F, Widiyastuti L. Optimization of water fraction gel formula of binahong leaf (Anredera cordifolia (Ten.) Steen) with gelling agent of sodium alginate and carboxymethyl chitosan combination. Tradit Med J 2018;23:97-105.

25. Piau JM. Carbopol gels: elastoviscoplastic and slippery glasses made of individual swollen sponges: meso-and macroscopic properties, constitutive equations and scaling laws. J NonNewtonian Fluid Mechnics 2007;144:1-29.

26. Verschoore M, Poncet M, Czernielewski J, Sorba V, Clucas A. Adapalene $0.1 \%$ gel has low skin-irritation potential. J Am Acad Dermatol 1997;36:S104-9.

27. Soliman SM, Abdel Malak NS, El Gazayerly ON, Abdel Rahim AA. Formulation of microemulsion gel systems for transdermal delivery of celecoxib: in vitro permeation, anti-inflammatory activity and skin irritation tests. Drug Discovery Ther 2010;4:459-71.

28. Dreher F, Walde P, Luisi PL, Elsner P. Human skin irritation studies of a lecithin microemulsion gel and of lecithin liposomes. Skin Pharmacol Physiol 1996;9:124-9.

29. Pelczar MJ, Chan ECS, Krieg NR. Microbiology. New York: McGraw-Hill; 1993. p. 578.

30. Masoodi MH, Ahmed B, Zargar IM, Khan SA, Khan S, Singh P. Antibacterial activity of whole plant extract of marrubium vulgare. Afr J Biotechnol 2008;7:86-7.

31. Patil AG, Koli SP, Patil DA. Pharmcognostical standardization and HPTLC fingerprint of averrhoa bilimbi (L.) fruits. J Pharm Res 2013;6:145-50.

32. Górniak I, Rafal B, Króliczewski J. Comprehensive review of antimicrobial activities of plant flavonoids. Phytochem Rev 2019;18:241-72.

33. Kumar S, Pandey AK. Chemistry and biological activities of flavonoids: an overview. Sci World J 2013;2013:1-16.

34. Nijveldt RJ, Van Nood ELS, Van Hoorn DE, Boelens PG, Van Norren K, Van Leeuwen PAM. Flavonoids: a review of probable mechanisms of action and potential applications. Am J Clin Nutr 2001;74:418-25. 
35. Kumar P, Sharma B, Bakshi N. Biological activity of alkaloids from solanum dulcamara l. Nat Prod Res 2009;23:719-23.

36. Raji P, Samrot AV, Keerthana D, Karishma S. Antibacterial activity of alkaloids, flavonoids, saponins and tannins mediated green synthesized silver nanoparticles against pseudomonas aeruginosa and bacillus subtilis. J Clust Sci 2019;20:881-95.

37. Mohanan S, Nabeela R, Bimal RKS. Formulation and evaluation of antimicrobial gels for the treatment of paronychia. Int J Appl Pharm 2018;10:161-7. 